\title{
Local and Regional Flap Approaches for the Repair of Postsurgical Tissue Defects in the Head and Neck Region
}

\section{Baș ve Boyunda Cerrahi Sonrası Olușan Defektlerin Onarımında Lokal ve Rejyonel Fleplerin Kullanımı}

Dinçer Altınel, (D) Gaye Toplu

University of Health Sciences Turkey, İstanbul Training and Research Hospital, Clinic of Plastic Surgery, İstanbul, Turkey

\begin{abstract}
Introduction: In this retrospective study, the indications and success, complication and mortality rates of local and regional flaps used in head and neck reconstruction were investigated.

Methods: Patients operated for head and neck reconstruction between the years 2014 and 2019 were included in this retrospective study.

Results: A total of 41 patients were included in the study. The mean patient age was $60.3 \pm 20.6$ (range: $8-89$ ). In $39.0 \%$ $(n=16)$ of patients, the pectoralis major muscle flap was used for reconstruction. In $17.1 \%(n=7)$ of patients, the local advancement flap was used. In all, $29 \%(n=12)$ of patients had squamous cell carcinoma, 19.5\% $(n=8)$ had basal cell carcinoma, and $14.6 \%(n=6)$ of patients had tracheoesophageal fistula. The overall complication rate was $29.2 \%$. The mortality rate was $2.4 \%(n=1)$.

Conclusion: In this retrospective study, it was objectively demonstrated that local regional pedicle flaps can be used safely in the repair of head and neck defects with correct patient analysis, wound site and defect evaluation, and flap planning.
\end{abstract}

Keywords: Head and neck reconstruction, local flaps, regional flaps

\section{öZ}

Amaç: Bu retrospektif çalıșmada baș ve boyun cerrahisinde kullanılan lokal ve rejyonel fleplerin endikasyonları, başarı komplikasyon ve mortalite oranları incelendi.

Yöntemler: Çalıșma retrospektif olarak planlandı. Bu çalıșmaya baş ve boyun rekonstrüksiyonu amacıyla 2014 ve 2019 yılları arasında kliniğimizde lokal ve rejyonel opere edilen hastalar dahil edildi.

Bulgular: Kırk-bir hasta çalıșmaya dahil edildi. Ortalama

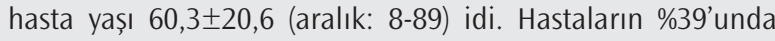
$(n=16)$ pektoral majör kas flebi, \%17'sinde $(n=12)$ lokal ilerletme flebi kullanıldı. Etiyoloji hastaların \%29'unda $(n=12)$ sküamöz hücreli karsinom, \%19,5’inde $(n=8)$ bazal hücreli karsinom ve \%14,6'sında $(n=6)$ trakeaözofageal fistül idi. Genel komplikasyon oranı \%29,2 olarak hesaplandı. Mortalite oranı $\% 2,4(n=1)$ idi.

Sonuç: Bu retrospektif çalıșmada lokal rejyonel pediküllü fleplerin doğru hasta, yara ve defekt analizi ve uygun planlama ile baş ve boyun defektlerinde güvenli bir şekilde ve yüksek başarı oranı ile kullanılabileceği objektif verilere dayanarak gösterilmektedir.

Anahtar Kelimeler: Baş ve boyun rekonstrüksiyonu, lokal flepler, rejyonel flepler

\section{Introduction}

Head and neck reconstruction is an important issue due to the special structure of the face and scalp. In particular, the facial region contains important and specific functional anatomical structures, especially the nose, ear, eye, and mouth. Reconstructive needs arise after various operative procedures, especially tumor surgery or events that cause soft tissue and skeletal damage, such as trauma. Reconstructing the most functional and stable structure possible should be the main goal of reconstructive surgery in cases that disrupt the normal anatomy of the orbital cavity, oral cavity, nasal pyramid, and ear. Tissue repair is performed according to the plastic surgery reconstruction pyramid that progresses from simple to more complex. According to this pyramidal approach, soft tissue repair is preferably performed with primary suturing, partial or full thickness skin graft, local flap, regional flap, and free flap options. Sometimes, these options are applied in combination to the patient's defect (1-4).
Address for Correspondence/Yazıșma Adresi: Dinçer Altınel MD, University of Health Sciences Turkey, İstanbul Training and Research Hospital, Clinic of Plastic Surgery, İstanbul, Turkey

Phone: +90 5057739530 E-mail: drdinceraltinel@yahoo.com ORCID ID: orcid.org/0000-0002-8287-7943

Cite this article as/Atıf: Altınel D, Toplu G. Local and Regional Flap Approaches for the Repair of Postsurgical Tissue Defects in the Head and Neck Region. İstanbul Med J 2021; 22(1): 8-12.
Received/Geliş Tarihi: 11.09 .2020 Accepted/Kabul Tarihi: 07.11.2020

(C) Copyright 2021 by the University of Health Sciences Turkey, Istanbul Training and Research Hospital/istanbul Medical Journal published by Galenos Publishing House.

(C) Telif Hakkı 2021 Sağlık Bilimleri Üniversitesi Istanbul Ĕgitim ve Araştırma Hastanesi/Istanbul Tıp Dergisi, Galenos Yayınevi tarafından basılmıștır. 
If possible, the damaged skeletal support tissue is repaired by rigid fixation of the broken fragments in a straight line with plate screws. If primary skeletal repair is not possible, the defect is repaired using a free bone graft, vascularized autogenous bone grafts, or allograft materials. The primary consideration is the patient's point of view. Accordingly, the correct approach is the simplest one for the patient. A free flap should not be considered if repair with other options is possible, and we should not use this trump card in the future, considering the need for further surgery. In most patients, a free flap is not required unless there is a strain on the surgical indication, and existing defects can be repaired with other options at a much lower risk of donor-site morbidity (5-7).

In this study, our aim was to evaluate the indications and success, complication, and mortality rates of local and regional flaps used in head and neck reconstruction.

\section{Methods}

The study was designed as a retrospective study. Patients operated on for head and neck reconstruction with regional and local flaps between the years 2014 and 2019 were included in the study. Ethics approval was obtained from the University of Health Sciences Turkey, İstanbul Training and Research Hospital Local Ethics Committee (approval number: 2474, date: 10.07.2020). Informed consent was obtained from all the patients. Patients who had primary and secondary graft repairs and microsurgical reconstructions were not included. The complication and mortality rates, pathological features, and success rates were investigated (Figure 1-4).

Local regional flaps were planned for chronic wound healing problems such as fistulas and repair of soft tissue defects after primary surgical interventions such as tumor excision, vascular malformation surgery, and cochlear implant placement. Scalp flaps with an axillary pattern (based on the occipital and posterior auricular vessels) were used, and skin grafts were applied to the flap donor areas in large scalp defects and defects after tumor surgery. Pectoralis muscle flaps with an axial circulation pattern were used for extensive tissue defects and chronic draining wounds after tracheoesophageal fistula or tumor excision and neck dissection surgery. Pectoral flap donor areas were mostly closed primarily. In late and simultaneous repairs of patients with cochlear implants exposing scalp defects with discharge and defects in the facial region after tumoral surgery, random transformation and rotation flaps were used, and donor areas were closed primarily.

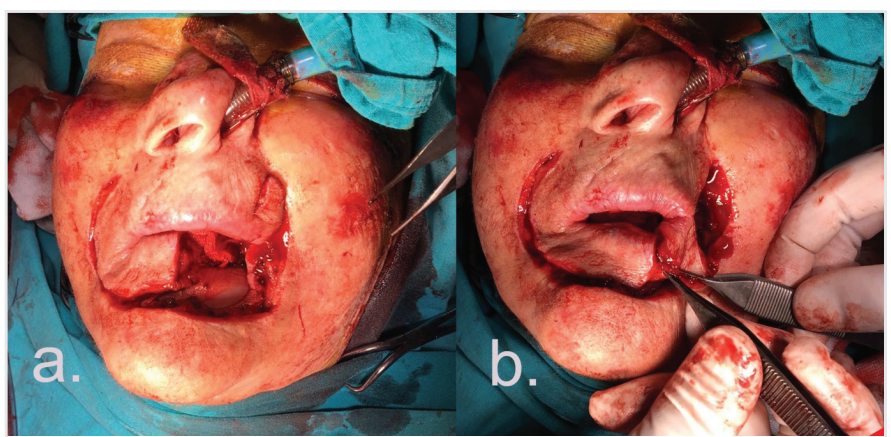

Figure 1. Peroperative photographs of a 68-year-old patient with a lower lip defect following squamous carcinoma excision (a) and reconstruction using Karapandzic and Estlander flaps (b)

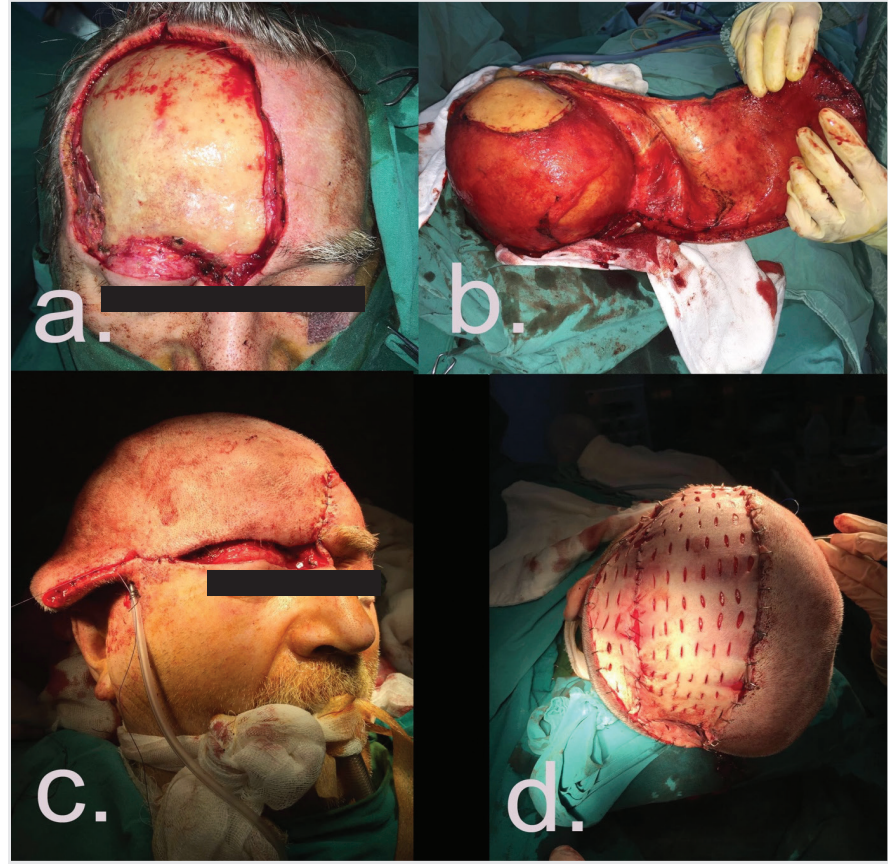

Figure 2. A 60-year-old patient with frontotemporal defect reconstruction using a scalp flap following microcystic adenoid carcinoma excision. Preoperative view of the defect. (a) Flap elevation (b) and insertion of the flap into the defect (c). Split thickness skin grafting was used to cover the donor area defect $(d)$

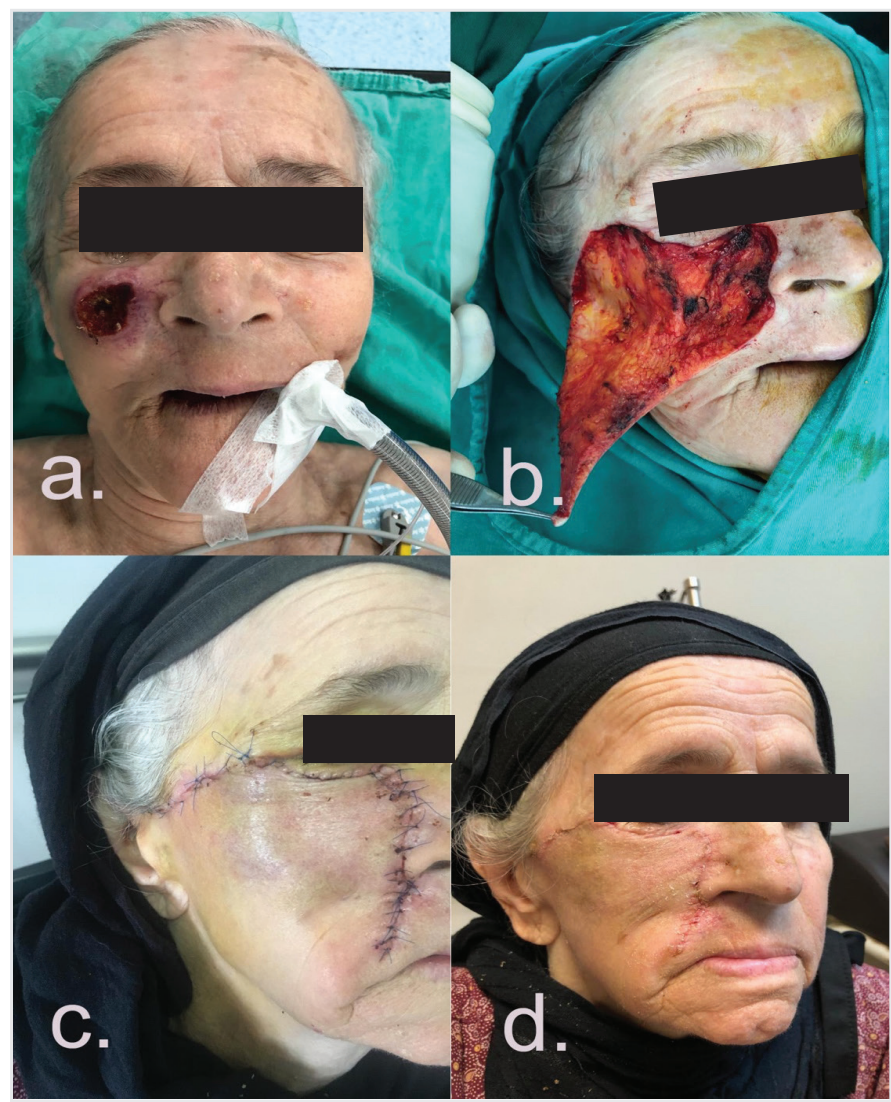

Figure 3. An 82-year-old patient with an infraorbital defect following dermal sarcoma excision (a) was repaired using a Mustarde cheek advancement flap (b). Photographs of the patients 1 week (c) and 1 month (d) following surgery 


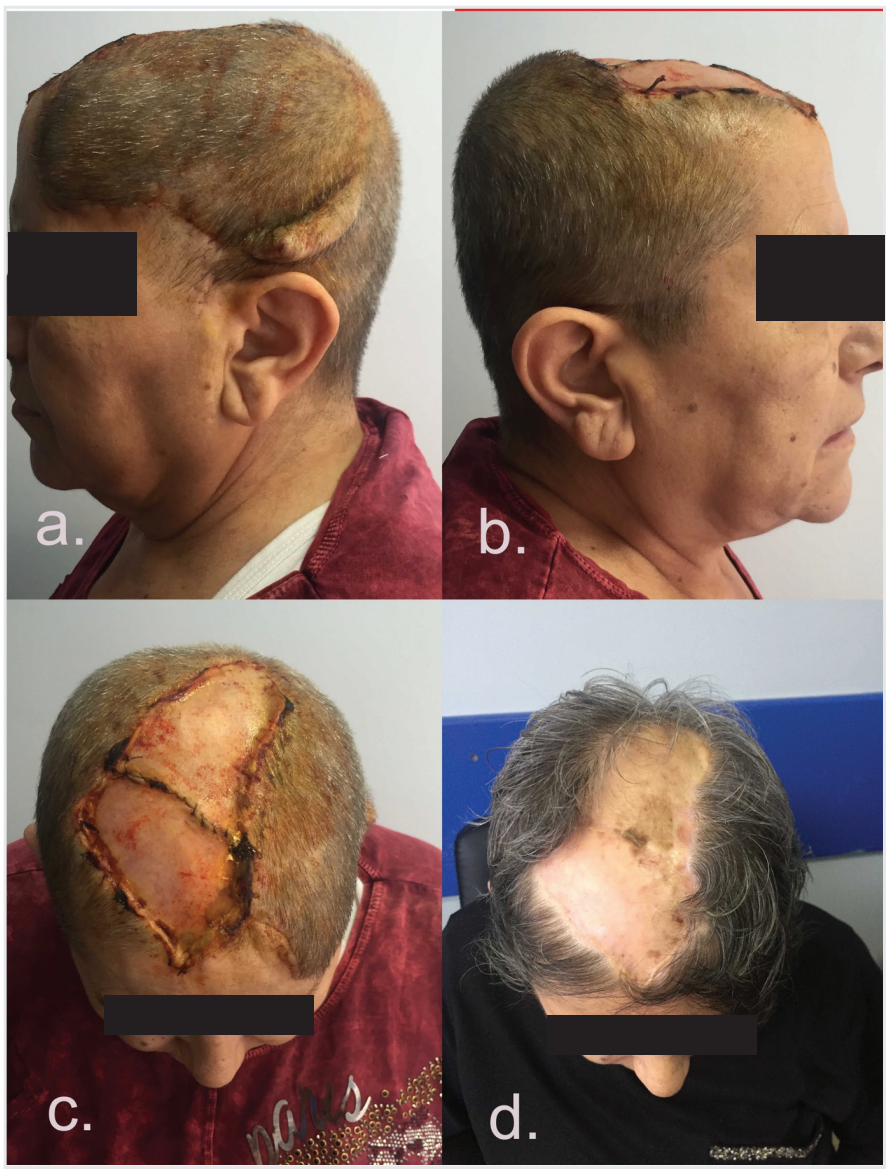

Figure 4. A 55-year-old patient with scalp flap reconstruction (a) following a skin defect due to wound infection and cerebrospinal fluid leak following vascular malformation surgery. The flap was based on superficial temporal and occipital vessels. The donor was repaired with a split thickness skin graft (b-d)

\section{Statistical Analysis}

Descriptive analysis was performed using GraphPad Prism 7.0 software (GraphPad Software, Inc., La Jolla, CA, USA).

\section{Results}

A total of 41 patients were included in the study. The mean patient age was $60.3 \pm 20.6$ (range: $8-89$ ), 33 of the patients were male, and 8 of the patients were female. The mean follow-up time was 3.1 \pm 1.2 years (Table 1). In $39.0 \%(n=16)$ of patients, the pectoralis major muscle flap was used for reconstruction. In $17.1 \%(n=7)$ of patients, a local advancement flap was used (Table 2). In all, 29\% $(n=12)$ of patients had squamous cell carcinoma, $19.5 \%(n=8)$ had basal cell carcinoma, and $14.6 \%(n=6)$ had tracheoesophageal fistula (Table 3 ). The overall complication rate was 29.2\%. In all, 3, 4, and 5 patients encountered hematoma, infection, and wound dehiscence in the postoperative period, respectively. Four revision surgeries were performed. The mortality rate was $2.4 \%(n=1)$. One patient died in the early postoperative period due to massive bleeding in the neck area (Table 4). Most infections resolved with local and systemic antibiotherapy. Suture line detachments and superficial
Table 1. Patient demographics $(n=41)$

\begin{tabular}{|l|l|l|}
\hline & $\begin{array}{l}\text { Mean (standard } \\
\text { deviation) }\end{array}$ & Range \\
\hline Mean age (years) & $60.3 \pm 20.6$ & $3-89$ \\
\hline Mean follow-up time (years) & $3.1 \pm 1.2$ & $1-6$ \\
\hline
\end{tabular}

Table 2. List of reconstructive methods $(n=41)$

\begin{tabular}{|l|l|l|}
\hline & Number & Percentage \\
\hline Pectoralis major flap & 16 & $39.0 \%$ \\
\hline Local advancement flap & 7 & $17.1 \%$ \\
\hline Frontal flap & 4 & $9.8 \%$ \\
\hline Nasolabial flap & 2 & $4.9 \%$ \\
\hline Limberg flap & 2 & $4.9 \%$ \\
\hline Karapandzic flap & 2 & $4.9 \%$ \\
\hline Fasciocutanous scalp flap & 2 & $4.9 \%$ \\
\hline Transposition flap & 2 & $4.9 \%$ \\
\hline Mustarde flap & 1 & $2.4 \%$ \\
\hline Estlander flap & 1 & $2.4 \%$ \\
\hline Rotation flap & 1 & $2.4 \%$ \\
\hline Deltopectoral flap & 1 & $2.4 \%$ \\
\hline
\end{tabular}

Table 3. Pathological features of the patients

\begin{tabular}{|c|c|c|}
\hline & Number & Percentage \\
\hline \multicolumn{3}{|l|}{ Squamous cell carcinoma } \\
\hline *Nasal squamous cell carcinoma & 3 & $7.3 \%$ \\
\hline *Lip squamous cell carcinoma & 5 & $12.2 \%$ \\
\hline *Ear squamous cell carcinoma & 1 & $2.4 \%$ \\
\hline *Intraoral squamous cell carcinoma & 1 & $2.4 \%$ \\
\hline *Neck squamous cell carcinoma & 1 & $2.4 \%$ \\
\hline *Cheek squamous cell carcinoma & 1 & $2.4 \%$ \\
\hline \multicolumn{3}{|l|}{ Basal cell carcinoma } \\
\hline *Nasal basal cell carcinoma & 4 & $9.8 \%$ \\
\hline *Upper lip basal cell carcinoma & 2 & $4.9 \%$ \\
\hline *Ear basal cell carcinoma & 2 & $4.9 \%$ \\
\hline Tracheoesophageal fistula & 6 & $14.6 \%$ \\
\hline Cochlear implant exposition & 4 & $9.8 \%$ \\
\hline Larynx ca & 3 & $7.3 \%$ \\
\hline Pharyngocutaneous fistula & 2 & $4.9 \%$ \\
\hline Facial malignant melanoma & 1 & $2.4 \%$ \\
\hline Intraoral retromolar epidermoid tumor & 1 & $2.4 \%$ \\
\hline Microcystic adnexial carcinoma & 1 & $2.4 \%$ \\
\hline Pleomorphic dermal sarcoma of right maxilla & 1 & $2.4 \%$ \\
\hline $\begin{array}{l}\text { Neck metastasis of lingual squamous cell } \\
\text { carcinoma }\end{array}$ & 1 & $2.4 \%$ \\
\hline Recurrent frontal mass & 1 & $2.4 \%$ \\
\hline
\end{tabular}




\begin{tabular}{|l|l|l|}
\hline \multirow{2}{*}{ Table 4. Complication and mortality rates following surgery } \\
\hline & Number & Percentage \\
\hline Hematoma & 3 & $7.3 \%$ \\
\hline Infection & 4 & $9.7 \%$ \\
\hline Wound dehiscence & 5 & $12.1 \%$ \\
\hline Revision surgeries & 4 & $9.7 \%$ \\
\hline Overall complication rate & 12 & $29.2 \%$ \\
\hline Mortality rate & 1 & $2.4 \%$ \\
\hline & & \\
\hline
\end{tabular}

wound healing problems were treated with appropriate dressings. No significant flap contraction was observed in the late period.

\section{Discussion}

In our study, the majority of patients were operated on with a pectoralis major flap. The complication rates were low, and the success rate was high. The pectoralis flap can be used in head defects up to the superior border of the temporalis muscle. Fasciocutanous scalp flaps can be used in scalp areas where the pectoralis flap is out of reach. The utilization of these two flaps alone can eliminate the need for microsurgical reconstruction in the majority of patients that require head and neck reconstruction. The only major group of patients that required microsurgical reconstruction in the head and neck region were those with major bone defects such as tumors of the mandible. In our series, there was only one mortality. This mortality was not directly related to the flap surgery but rather due to postoperative abundant bleeding in the cervical lymph node dissection area.

Both random and axial pattern loco regional flaps were included the study. Local flaps with random and axial circulation patterns are the commonly preferred flap options in the reconstruction of the head and neck region and can be applied easily in direct proportion to the surgical experience when planned correctly. Random pattern local flaps are fed randomly from the subcutaneous vascular network and do not have a distinct feeder vessel, depending on the circulation pattern. Axial pattern flaps, on the other hand, are flaps with a distinct dominant nourishment vessel and are lifted over their pedicle. They can be planned much longer and narrower than random flaps and can even be designed as an island flap only on the vascular pedicle. Thus, it is an advantage to have a much wider range of motion axis. We also designate local flaps with names such as transposition flap, rotation flap, bilobed flap, or advancement flap, according to the surgical design of the flap (8-11).

Transposition flaps can be safely planned with the long side a maximum of three times the length of the short side. Rotation flaps are planned as semicircles adjacent to the defect and are slid over a pivot point. Unlike rotational flaps, advancement flaps are designed adjacent to the defect and are directly advanced to the defect, creating no rotational axis movement. Single and multiple z-plasty, rhomboid flaps, v-y flaps, and w-plasty flaps are other local flap designs that can be considered. Random flaps are local flaps that require good surgical planning; otherwise, their vascular safety may not be very high. We often preferred them to cover small defects in the head and neck area. The random flap donor area is mostly closed primarily, and a second local flap or skin graft is rarely used. Care should be taken to ensure that the adaptation of the flap to the defect area is tension-free. Otherwise, detachments due to marginal necrosis and delays in healing are observed in the suture lines. If the flap is planned with too high length to width ratio, partial or full thickness necrosis is inevitable in its distal area (12-18).

We performed soft tissue repairs by using flaps with a local random circulation pattern and a regional axial pattern in the patients included in our current study. All of these patients with chronic wounds and tissue defects had pioneering surgeries for various reasons. Postoperative recovery problems and soft tissue deficiencies were repaired with local and regional flaps as a result of surgical planning. Axial patterned local and regional flaps are much safer than those fed randomly. Due to their vascular safety, they can be planned much larger and adapted to more distant regional defect areas. According to the course of the dominant nourishing pedicle within the tissues, axial flaps can be elevated as skin flaps, fasciocutaneous flaps, muscle flaps, muscle skin flaps, and muscle skin and bone flaps. It is important to decide the flap to be used according to the size and depth of the defect area, the vascular quality of the wound bed, the presence of infection, and the required tissue deficiency.

\section{Conclusion}

The use of local and regional tissues in reconstruction shortens the duration of the surgical procedure, as there is no need for a second surgical team and work area and the need for position adjustment for the patient during the operation is minimal. In addition, since neighboring tissues are used, similar tissue properties are transferred, and better tissue adaptation is achieved. Axial pattern flaps such as the scalp flap and pectoral flap are preferable in more problematic and large defects.

\section{Acknowledgment}

We would like to thank Dr. Merdan Serin for his support in the planning and writing of the study.

\section{Ethics}

Ethics Committee Approval: Ethics approval was obtained from the University of Health Sciences Turkey, İstanbul Training and Research Hospital Local Ethics Committee (approval number: 2474, date: 10.07.2020).

Informed Consent: Informed consent was obtained from all the patients.

Peer-review: Externally peer-reviewed.

Authorship Contributions: Surgical and Medical Practices - D.A., G.T.; Concept - D.A., G.T.; Design - D.A., G.T.; Data Collection or Processing D.A., G.T.; Analysis or Interpretation - D.A.; Literature Search D.A.; Writing - D.A.

Conflict of Interest: No conflict of interest was declared by the authors.

Financial Disclosure: The authors declared that this study received no financial support. 


\section{References}

1. Baker SR. Regional flaps in facial reconstruction. Otolaryngol Clin North Am 1990; 23: 925-46.

2. Chang JW, Lim JH, Lee JH. Reconstruction of midface defects using local flaps: An algorithm for appropriate flap choice. Medicine 2019: 98: e18021.

3. de S. Chapter-040 Local Flaps in Facial, Head and Neck Surgery 2009; 529-42.

4. Degner DA. Facial reconstructive surgery. Clin Tech Small Anim Pract 2007; 22: 82-8.

5. El-Marakby H. Deep Inferior Epigastric Perforator Flap in Breast Reconstruction: Egyptian Experience. Journal of Reconstructive Microsurgery 2006: 22.

6. Field LM. Scalp flaps. The J Dermatol Surg Oncol 1991; 17: 190-99.

7. Gundeslioglu AO, Selimoglu MN, Doldurucu T, Bekerecioglu M. Reconstruction of large anterior scalp defects using advancement flaps. J Craniofac Surg 2012; 23: $1766-9$.

8. Hanasono MM. Use of reconstructive flaps following total laryngectomy. JAMA Otolaryngol Head Neck Surg 2013; 139: 1163.

9. Kim MC, Ko YI, Shim HS. econstruction of scalp and forehead defect with local transposition split skin flap and remnant full-thickness skin graft. J Plast Reconstr Aesthet Surg 2013; 66: 1436-8.
10. Lam D, Strauss RA. Local and regional flaps of the head and neck. Oral Maxillofac Surg Clin North Am 2014; 26: xi-xii.

11. Larrabee WF. Design of local skin flaps. Otolaryngol Clin North Am 1990; 23: 899-923.

12. Learned KO, Malloy KM, Loevner LA. Myocutaneous flaps and other vascularized grafts in head and neck reconstruction for cancer treatment. Magn Reson Imaging Clin N Am 2012; 20: 495-513.

13. Lucas JB. The Physiology and Biomechanics of Skin Flaps. Facial Plast Surg Clin North Am 2017; 25: 303-11.

14. Ray E. Head and Neck Reconstructive Surgery. Cancer Treat Res 2018; 174 : 123-43.

15. Tenna S, Brunetti B, Aveta A, Poccia I, Persichetti P. Scalp reconstruction with superficial temporal artery island flap: clinical experience on 30 consecutive cases. J Plast Reconstr Aesthet Surg 2013; 66: 660-6.

16. Zhong T, Gullane PJ, Neligan P. Bilateral latissimus dorsi flaps for the reconstruction of extensive scalp defects. Can J Plast Surg 2003; 11: 79-82.

17. Patel SY, Meram AT, Kim DD. Soft Tissue Reconstruction for Head and Neck Ablative Defects. Oral Maxillofac Surg Clin North Am 2019; 31: 39-68.

18. Olsson AB, Dillon J, Kolokythas A, Schlott BJ. Practice Guidelines: Reconstructive Surgery. J Oral Maxillofac Surg 2017; 75(Suppl 1): e264-e301. 